\title{
Teacher's Perception of Thermodynamic Law Module Developed in Training through Student's Critical Thinking Skills
}

\author{
Eko Risdianto \\ Universitas Bengkulu, Indonesia \\ e-mail: eko_risdianto@unib.ac.id \\ Jeni Fitria \\ Universitas Bengkulu, Indonesia \\ e-mail: jfitria@gmail.com \\ Henny Johan \\ Universitas Bengkulu, Indonesia \\ e-mail: hennyjohan@gmail.com \\ Julie Simon Macariola \\ Philippine Christian University, Philippines \\ e-mail: juliesimonmac@gmail.com
}

Article History: Received on 18 July 2020, Revised on 22 July 2020, Published on 1 August 2020

\begin{abstract}
This study determined teacher's perceptions about the ability of modules developed in training students' critical thinking skills. This research is a part of research and development with the development model used, namely 3D Development, namely Define, Design, and Develop which was adapted. The instruments used were observation sheets, student needs questionnaire sheets and teacher perception questionnaire sheets. Questionnaire needs were given to 100 students of class XI Science while perception questionnaires were given to 30 high school/vocational school physics teachers. Data analysis techniques used are quantitative analysis techniques and qualitative analysis techniques. The instrument used to obtain perception data was categorized as valid with a value of $\mathrm{Va}=3.11$ and reliable with a Crobach's Alpha Coefficient calculated 0.925 greater than the standard Crobach's Alpha Coefficient value of 0.60 . The results of the perception questionnaire analysis obtained an average percentage of teacher perceptions of $77.87 \%$ with a very good category.
\end{abstract}

Keywords: Teacher's Perception; Thermodynamic Law Module; Critical Thinking Skills

\section{A. Introduction}

Education is one of the main factors in creating a generation of people with high insight and good character (Purmadi \& Surjono, 2016). The development of science and technology is increasingly pushing for renewal efforts in the use of technological outcomes in the learning process (Purwaningtyas \& Hariyadi, 2017).

Life in the global era demands various educational changes, one of which is the curriculum. This is an awareness that changes and curriculum development are felt very necessary to improve the education system in Indonesia (Liani et al, 2018). In Indonesia now, schools, 
especially the high school, have implemented the 2013 Curriculum and some have even implemented the Revised 2013 Curriculum (Peranti et al, 2019). The 2013 curriculum development is based on competence in the context of 21 st century education (Handayani et al, 2018). The learning process in the implementation of the 2013 curriculum in the education unit is held interactively, inspirational, fun, challenging, motivating students to actively participate, as well as providing sufficient space for initiative, creativity, and independence in accordance with the talents, interests and physical and psychological development of students (Mertayasa et al, 2018).

Physics learning currently emphasizes the orientation of students as subjects in the learning process (Fadilah et al, 2018). One of the skills students must have according to the Department of Defense Education Activity (DoDEA) is critical thinking skills (Ningsih et al, 2018). Ennis in (Sumarmo et al, 2012) defines critical thinking as reflective thinking that is reasonable and focused on determining what is believed or done. Critical thinking skills need to be equipped for every student to be able to survive in a competitive society (Syamsu, 2020). One of the tips to practice students' critical thinking skills is the use of teaching materials that are developed based on indicators of critical thinking. The initial step of critical thinking is to focus on the problem or identify the problem well, find out what the real problem is and how to prove it. The next step is to formulate arguments that support conclusions, look for evidence that supports the reasons for a conclusion so that conclusions can be accepted or in other words the reasons given must and in accordance with the conclusions. If the reasons stated are correct, then it must be shown how strong the reason can support the conclusions made (Mahmuzah, 2015).

A module is a learning package that deals with a unit of subject matter. Students can achieve and complete their learning material by studying individually, with modules students can control their abilities and intensity of learning (Auliya \& Kosim, 2017). The use of modules in teaching and learning activities not only looks at the teacher's activities alone, but also involves students actively in learning. Using modules also creates an independent learning process (Sukiminiandari et al, 2015). the benefits derived from learning by applying modules include. a) Increase students' motivation, b) After evaluating, the teacher and students know in which part of the module that students have succeeded and in which part of the module they have not succeeded, c) Students achieve results according to their ability, d) Materials lessons are divided more evenly in one semester (Ibrahim \& Yusuf, 2019)

Based on the things that have been described above, it is necessary to develop a module to train students 'critical thinking skills and it is necessary to collect teacher perceptions data to find out if the module developed is appropriate to be used to train students' critical thinking skills.

\section{B. Methods}

This type of research is research and development (Research and Development). Research and development methods (Research and Development) are research methods used to produce certain products, and test the effectiveness of these products (Sugiyono, 2010). The research and development model used in this study can be seen in Figure 1. 


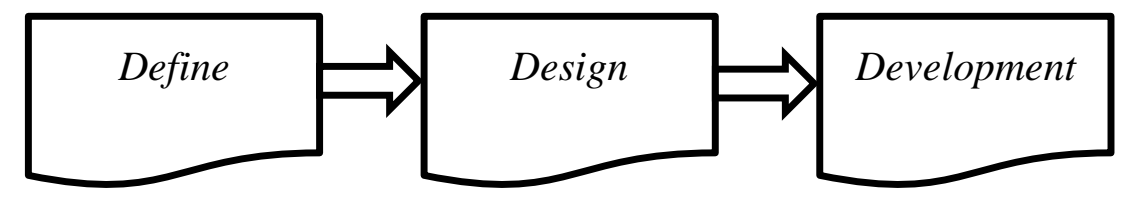

Figure 1 Steps of the 3D Model

(Sriwahyuni et al., 2019)

The research and development model used is the 4D (Four D Models) development model which is limited to the development stage. The limitation of the 4D model to 3D is due to the limited time and cost, so this research is only carried out with three stages namely define, design, and development. The research conducted will produce a product in the form of a learning module.

The module developed is a physics learning module for thermodynamic law material for high school class XI to practice students' critical thinking skills. In this study the validity and reliability of the perception questionnaire was used. Questionnaire is said to be valid if the validity level is greater or equal to 3, and it is said to be reliable if the value of the Crobach's Alpha Coefficient count is greater than the standard Crobach's Alpha Coefficient value of 0.60 (Triana \& Oktavianto, 2013).

Teacher perception data collection is done by using perception questionnaire sheets. Analysis of the results of the perception questionnaire was carried out quantitatively using the following formula.

$$
p=\frac{n}{N} \times 100 \%
$$

Where $\mathrm{P}$ is the percentage of perception results, $\mathrm{n}$ is the total score of expert judgment, and $\mathrm{N}$ is the maximum score possible. For the Likert scale the interpretation of the scores can be seen in table 1.

Table 1. Interpretation of Likert Scale

\begin{tabular}{cc}
\hline Percentage (\%) & Category \\
\hline $0 \%-25 \%$ & Very not good \\
$26 \%-50 \%$ & Not good \\
$51 \%-75 \%$ & Good \\
$76 \%-100 \%$ & Very good \\
\hline
\end{tabular}

From the data from this interpretation, the research can be said to be successful and valid or very valid if the questionnaire data processing produces a score between $51 \%$ to $100 \%$ or within the criteria of "Good" and "Very Good" (Hayati et al., 2015). 
Volume 1 (1) 2020

E-ISSN: 2723-6919

\section{Results and Discussion}

\section{Define phase}

The first activity is problem analysis which is carried out through a process of observation and dissemination of the needs of the module to 100 students of class XI Science. Based on the analysis of the questionnaire the need for modules in learning obtained an average percentage data of $81.87 \%$, so it can be concluded that students strongly agree the development of physics learning modules in the concept of thermodynamic law.

\section{Design phase}

At this stage, the researcher chooses the media and learning material to be developed. The selected media is electronic media with the help of 3D PageFlip Professional software and QR Code. The material implied in this study is the Law of Thermodynamics for High School Grade XI students. Learning modules are designed as teaching materials that students can use anytime and anywhere. The learning module as teaching material is more emphasized to train students' critical thinking skills.

\section{Develop phase}

Products in the form of thermodynamic law modules that have been developed can be seen in Figure 2-10.

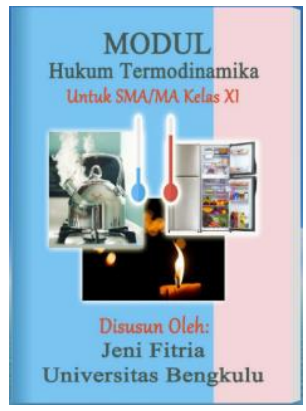

Figure 2 Cover Page

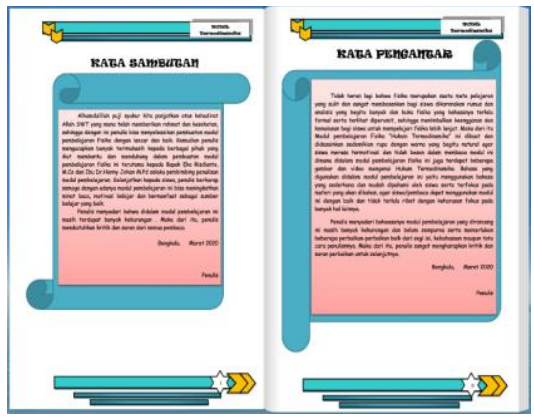

Figure 3 Welcome and Introduction

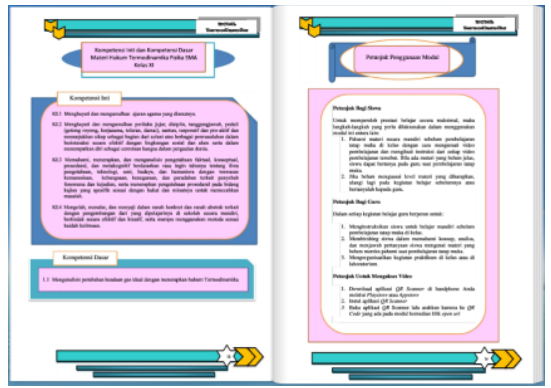

Figure 4 Core Competencies, basic Competencies, and Instructions Using Modules 


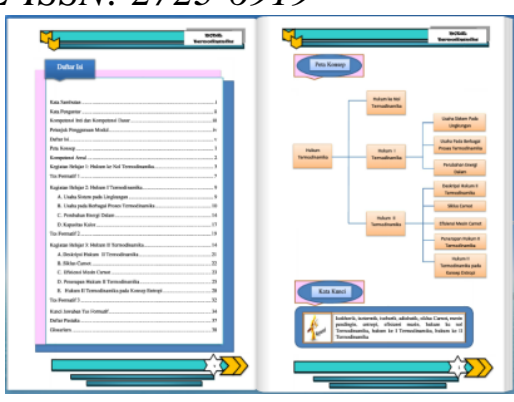

Figure 5 Basic Contents, Concept Maps and Keywords

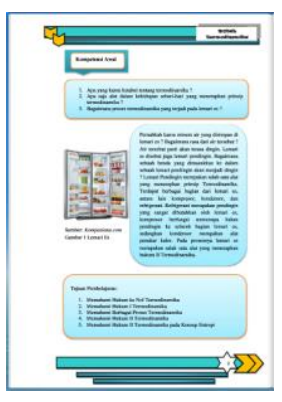

Figure 6 Initial Competence and Learning Objectives

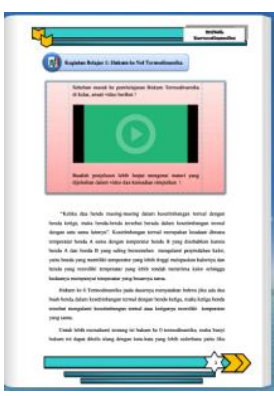

Figure 7 Video

Display on 3D

PageFlip

Professional

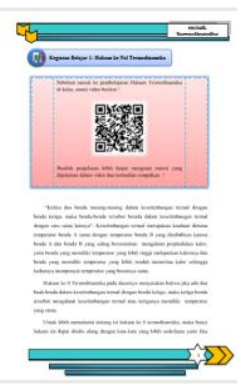

Figure 8 Video Display with QR Code

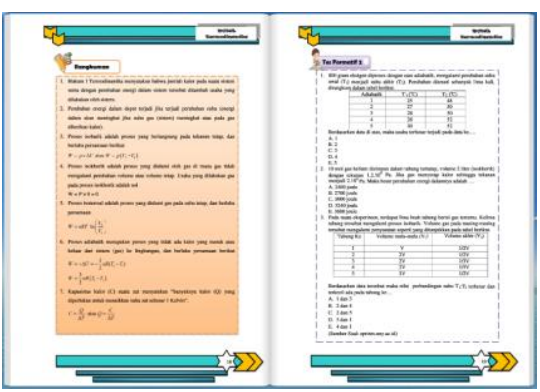

Figure 9 Summary and Formative Test

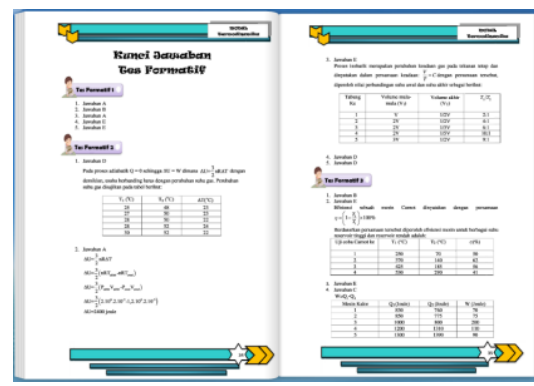

Figure 10 Key To Formative Test Answer

In this study an analysis of the validity and reliability of the perception questionnaire used. From the analysis, the results are obtained that all items in the questionnaire perception are valid. In more detail can be seen in the following table.

Table 1: Validity Test Results for Items of Question on Perception Questionnaire

\begin{tabular}{|c|c|c|c|c|c|c|c|c|c|c|c|}
\hline \multirow{2}{*}{ Respondents } & \multicolumn{10}{|c|}{ Question } \\
\cline { 2 - 14 } & $\mathbf{1}$ & $\mathbf{2}$ & $\mathbf{3}$ & $\mathbf{4}$ & $\mathbf{5}$ & $\mathbf{6}$ & $\mathbf{7}$ & $\mathbf{8}$ & $\mathbf{9}$ & $\mathbf{1 0}$ & $\mathbf{1 1}$ \\
\hline 1 & 4 & 4 & 4 & 4 & 4 & 4 & 4 & 4 & 4 & 4 & 4 \\
\hline 2 & 3 & 3 & 4 & 3 & 3 & 3 & 3 & 3 & 4 & 3 & 3 \\
\hline 3 & 3 & 3 & 3 & 3 & 3 & 3 & 3 & 3 & 3 & 3 & 3 \\
\hline 4 & 4 & 3 & 3 & 3 & 3 & 3 & 3 & 3 & 3 & 3 & 3 \\
\hline 5 & 3 & 3 & 4 & 4 & 3 & 4 & 4 & 4 & 3 & 4 & 3 \\
\hline 6 & 3 & 3 & 4 & 4 & 4 & 3 & 3 & 3 & 3 & 4 & 4 \\
\hline 7 & 3 & 3 & 3 & 3 & 3 & 3 & 3 & 3 & 3 & 3 & 3 \\
\hline 8 & 3 & 3 & 3 & 3 & 3 & 3 & 3 & 3 & 3 & 3 & 3 \\
\hline 9 & 3 & 3 & 3 & 3 & 3 & 3 & 3 & 3 & 3 & 3 & 3 \\
\hline 10 & 4 & 3 & 4 & 3 & 3 & 3 & 3 & 3 & 3 & 3 & 3 \\
\hline 11 & 3 & 3 & 3 & 3 & 3 & 3 & 3 & 3 & 3 & 3 & 3 \\
\hline 12 & 4 & 3 & 3 & 3 & 3 & 3 & 3 & 3 & 3 & 3 & 4 \\
\hline 13 & 4 & 3 & 3 & 3 & 3 & 3 & 3 & 3 & 3 & 3 & 3 \\
\hline
\end{tabular}


Volume 1 (1) 2020

E-ISSN : 2723-6919

\begin{tabular}{|c|c|c|c|c|c|c|c|c|c|c|c|}
\hline 14 & 4 & 4 & 4 & 4 & 4 & 4 & 4 & 4 & 4 & 4 & 4 \\
\hline 15 & 3 & 3 & 3 & 3 & 4 & 3 & 3 & 3 & 3 & 3 & 4 \\
\hline 16 & 3 & 3 & 4 & 4 & 3 & 3 & 3 & 3 & 4 & 3 & 3 \\
\hline 17 & 3 & 3 & 3 & 3 & 3 & 3 & 3 & 3 & 3 & 3 & 3 \\
\hline 18 & 3 & 3 & 3 & 3 & 3 & 3 & 3 & 3 & 3 & 3 & 3 \\
\hline 19 & 3 & 3 & 3 & 3 & 3 & 2 & 2 & 3 & 3 & 2 & 2 \\
\hline 20 & 3 & 3 & 2 & 2 & 2 & 2 & 2 & 2 & 2 & 2 & 3 \\
\hline 21 & 3 & 3 & 3 & 3 & 3 & 3 & 3 & 3 & 3 & 3 & 3 \\
\hline 22 & 3 & 3 & 3 & 3 & 3 & 3 & 3 & 3 & 3 & 3 & 4 \\
\hline 23 & 3 & 3 & 3 & 4 & 4 & 3 & 3 & 3 & 4 & 4 & 3 \\
\hline 24 & 3 & 3 & 3 & 3 & 3 & 3 & 3 & 3 & 3 & 2 & 3 \\
\hline 25 & 3 & 3 & 3 & 3 & 3 & 3 & 3 & 3 & 3 & 3 & 3 \\
\hline 26 & 3 & 3 & 3 & 3 & 3 & 3 & 3 & 3 & 3 & 3 & 3 \\
\hline 27 & 3 & 3 & 3 & 3 & 3 & 3 & 3 & 3 & 3 & 3 & 3 \\
\hline 28 & 3 & 3 & 3 & 3 & 3 & 3 & 3 & 3 & 3 & 3 & 3 \\
\hline 29 & 3 & 3 & 3 & 3 & 3 & 3 & 3 & 3 & 3 & 3 & 3 \\
\hline 30 & 3 & 3 & 3 & 3 & 3 & 3 & 3 & 3 & 3 & 3 & 3 \\
\hline Sum & 96 & 92 & 96 & 95 & 94 & 91 & 91 & 92 & 94 & 92 & 95 \\
\hline & 3.2 & 3.067 & 3.2 & 3.167 & 3.133 & 3.033 & 3.033 & 3.067 & 3.133 & 3.067 & 3.167 \\
\hline Category & Valid & Valid & Valid & Valid & Valid & Valid & Valid & Valid & Valid & Valid & Valid \\
\hline
\end{tabular}

From table 1 it can be seen that all questions have a validity level above 3 which means that all items in the teacher's perception questionnaire are valid and for an average Va value of 3.115 are also categorized valid.

Besides being valid, the teacher's perception questionnaire used was also reliable. In more detail, you can see in the following table.

Table 2: Results of Reliability Tests on Question Items in Perception Questionnaire

\begin{tabular}{|c|c|c|c|}
\hline $\begin{array}{c}\text { Number Of } \\
\text { Question } \\
\text { Items }\end{array}$ & $\begin{array}{c}\text { Crobach's Alpha } \\
\text { Coefficients are } \\
\text { Calculated }\end{array}$ & $\begin{array}{c}\text { Crobach's Alpha } \\
\text { Coefficients Default }\end{array}$ & Information \\
\hline 11 & 0,925 & 0,60 & Reliabel \\
\hline
\end{tabular}

From table 2, it can be seen that the calculated value of Crobach's Alpha coefficient is greater than the standard Crobach's Alpha coefficient value so that the perception questionnaire can be said to be reliable.

In this study also conducted data collection on teacher perceptions about the ability of modules developed in training students' critical thinking skills. The teacher's perception of the module's ability to practice critical thinking skills was obtained from a questionnaire data consisting of 11 questions. Based on questionnaire data filled out by 30 respondents who are high school physics teachers it is known that the modules developed are in the very good category with a percentage of $77.87 \%$ of $100 \%$. The $100 \%$ percentage is the ideal maximum 
Journal of Social Work and Science Education

Volume 1 (1) 2020

E-ISSN: $2723-6919$

percentage for this assessment. The results of teachers' perceptions about the module's ability to practice critical thinking skills in more detail can be seen in table 3 .

Table 3 Results of Teacher's Perception Data About Module Capabilities in Practicing Critical Thinking Skills

\begin{tabular}{ccccc}
\hline Validator & $\begin{array}{c}\text { Total } \\
\text { Score (n) }\end{array}$ & Max Score (N) & $\begin{array}{c}\text { Percentage } \\
P=\frac{n}{N} x 100 \%\end{array}$ & Category \\
\hline $\begin{array}{c}30 \text { High } \\
\text { School }\end{array}$ & 1028 & 1320 & $77,87 \%$ & Very Good \\
$\begin{array}{c}\text { Physics } \\
\text { Teacher }\end{array}$ & & & & \\
\hline
\end{tabular}

\section{Conclusion}

Based on the analysis results, the questionnaire used in this study was categorized as valid with an average value of validity level of 3.115 and reliable with a calculated value of 0.925 greater than the value of r-table of 0.361 . Based on the teacher's perception data about the ability of the module in training students' critical thinking skills carried out by 30 high school physics teachers, it was concluded that the module developed was able to train students' critical thinking skills because they received a positive response with a percentage obtained by $77.87 \%$ with the category very good.

\section{E. Acknowledgement}

We would like to express our special thanks and gratitude to all high school/vocational physics teachers who have helped to fill in the teacher's perception questionnaire distributed online.

\section{REFERENCE}

Auliya, M., \& Kosim, K. (2017). Pengembangan Modul Fisika Materi Optik Dengan Pendekatan Saintifik Berbasis Fenomena Alam Untuk Meningkatkan Efektivitas Belajar Siswa SMA [Development of Physics Modules for Optical Materials Using Scientific Approaches Based on Natural Phenomena to Improve the Effectiveness of High School Student Learning]. Jurnal Pijar Mipa, 12(2), 71-80. https://doi.org/10.29303/jpm.v12i2.344

Fadilah, S., Purwanto, A., \& Risdianto, E. (2018). Penerapan Model Inkuiri Terbimbing Untuk Meningkat Sikap Ilmiah Dan Hasil Belajar Siswa Pada Konsep Alat-Alat Optik Kelas XI SMAN 1 Mukomuko [Implementation of Guided Inquiry Model to Increase Scientific Attitudes and Student Learning Outcomes on the Concept of Optical Devices Class XI SMAN 1 Mukomuko]. Jurnal Kumparan Fisika, 1, 8-14.

Handayani, M. W., Swistoro, E., \& Risdianto, E. (2018). Pengaruh Model Pembelajaran Problem Solving Fisika Terhadap Kemampuan Penguasaan Konsep Dan Kemampuan Pemecahan Masalah Siswa Kelas X MIPA SMAN 4 Kota Bengkulu [The Effect of Physics Problem Solving Learning Model on Concept Mastery Ability and Problem 
Solving Ability in Class X MIPA Students of SMAN 4 Bengkulu City]. Jurnal Kumparan Fisika, 1(3), 36-44.

Hayati, S., Budi, A. S., \& Handoko, E. (2015). Pengembangan Media Pembelajaran Flipbook Fisika Untuk Meningkatkan Hasil Belajar Peserta Didik [Development of Physics Flipbook Learning Media To Improve Student Learning Outcomes]. Prosiding Seminar Nasional Fisika (E-Jurnal) SNF2015, 4, 49-54.

Ibrahim, E., \& Yusuf, M. (2019). Implementasi Modul Pembelajaran Fisika Dengan Menggunakan Model React Berbasis Kontekstual Pada Konsep Usaha Dan Energi [Implementation of Physics Learning Modules Using React Model Based on Contextual Concepts on Business and Energy]. Jambura Physics Journal, 1(1), 1-13. https://doi.org/10.34312/jpj.v1i1.2281

Liani, E., Hamdani, D., \& Risdianto, E. (2018). Penerapan Model Problem Based Learning Dengan Metode Brainstorming Untuk Meningkatkan Kemampuan Pemecahan Masalah Siswa Di SMAN 3 Kota Bengkulu [Application of Problem Based Learning Model with Brainstorming Method to Improve Students' Problem Solving Ability in SMAN 3 Bengkulu City]. Jurnal Kumparan Fisika, 1, 20-24.

Mahmuzah, R. (2015). Peningkatan Kemampuan Berpikir Kritis Matematis Siswa Smp Melalui Pendekatan Problem Posing [Increased Mathematical Critical Thinking Ability of Junior High School Students Through Problem Posing Approach]. Jurnal Peluang, 4(1), 64-72. https://doi.org/10.35194/jp.v6i2.123

Mertayasa, I. N. E., Agustini, K., \& Santyasa, I. W. (2018). Efektivitas E-Modul Berorientasi Modalitas Gaya Belajar Pada Mata Pelajaran Komunikasi Data Kelas XI TKJ Di SMK Negeri 3 Singaraja [Effectiveness of E-Module Oriented Learning Style Modalities in Data Communication Subjects for Class XI TKJ in SMK Negeri 3 Singaraja]. Seminar Nasional Pendidikan Teknik Informatika (SENAPATI), 9(September), 81-84.

Ningsih, D. R., Ramalis, T. R., \& Purwana, U. (2018). Pengembangan Tes Keterampilan Berpikir Kritis Berdasarkan Analisis Teori Respon Butir [Development of Critical Thinking Skills Test Based on Analysis of Item Response Theory]. Jurnal Wahana Pendidikan Fisika, 3(2), 45-50.

Peranti, Purwanto, A., \& Risdianto, E. (2019). Pengembangan Media Pembelajaran Permainan Mofin (Monopoli Fisika Sains) Pada Siswa SMA Kelas X [Development of Learning Media Game Mofin (Monopoly of Physics Science) In High School Students Grade X]. Jurnal Kumparan Fisika, 2(1), 41-47.

Purmadi, A., \& Surjono, H. D. (2016). Pengembangan Bahan Ajar Berbasis Web Berdasarkan Gaya Belajar Siswa Untuk Mata Pelajaran Fisika [Development of WebBased Teaching Materials Based on Student Learning Styles for Physics Subjects]. Jurnal Inovasi Teknologi Pendidikan, 151. https://doi.org/10.21831/jitp.v3i2.8285 
Volume 1 (1) 2020

E-ISSN: 2723-6919

Purwaningtyas, W. D. D., \& Hariyadi, I. (2017). Pengembangan Modul Elektronik Berbasis Online Dengan Program Edmodo [Online-Based Electronic Module Development with Edmodo Program]. Jurnal Pendidikan, 2(1), 123, 121-129. https://doi.org/10.17977/jp.v2i1.8471

Sriwahyuni, I., Risdianto, E., \& Johan, H. (2019). Pengembangan Bahan Ajar Elektronik Menggunakan Flip Pdf Professional Pada Materi Alat-Alat Optik Di SMA [Development of Electronic Teaching Materials Using Professional Flip Pdf on Optical Equipment Materials in High Schools]. Jurnal Kumparan Fisika, 2(3), 145152. https://doi.org/10.33369/jkf.2.3.145-152

Sugiyono. (2010). Metode Penelitian Pendidikan (Pendekatan Kuantitatif, Kualitatif, Dan $R \& D)$ [Educational Research Methods (Quantitative, Qualitative, and $R \& D$ Approaches)]. Alfabeta.

Sukiminiandari, Y. P., Budi, A. S., \& Supriyati, Y. (2015). Pengembangan Modul Fisika Dengan Pendekatan Saintifik [Development of Physics Modules with Scientific Approaches]. Prosiding Seminar Nasional Fisika, 4, 161-164.

Sumarmo, U., Hidayat, W., Zukarnaen, R., Hamidah, M., \& Sariningsih, R. (2012). Kemampuan Dan Disposisi Berpikir Logis, Kritis, Dan Kreatif Matematik (Eksperimen Terhadap Siswa SMA Menggunakan Pembelajaran Berbasis Masalah Dan Strategi Think-Talk-Write)[ Ability and Disposition of Logical, Critical, and Mathematical Creative Thinking (Experiments on High School Students Using Problem-Based Learning and Think-Talk-Write Strategies)]. Jurnal Pengajaran Matematika Dan Ilmu Pengetahuan Alam, 17(1), 17-33. https://doi.org/10.18269/jpmipa.v17i1.228

Syamsu, F. D. (2020). Pengembangan Lembar Kerja Peserta Didik Berorientasi Pembelajaran Discovery Learning Untuk Meningkatkan Keterampilan Berpikir Kritis Siswa [Development of Student Worksheets Oriented Learning Discovery Learning To Improve Students' Critical Thinking Skills]. Genta Mulia, 11(1), 65-79.

Triana, D., \& Oktavianto, W. O. (2013). Relevansi Kualifikasi Kontraktor Bidang Teknik Sipil Terhadap Kualitas Pekerjaan Proyek Konstruksi Di Provinsi Banten [The Relevance of Civil Engineering Contractor Qualifications to the Quality of Construction Project Work in Banten Province]. Jurnal Fondasi, 1(1), 182-190. 